\title{
Glutamate Neurotransmission in Psychotic Disorders and Substance Abuse
}

\author{
Berit Kerner $^{*}$ \\ Department of Psychiatry and Biobehavioral Sciences, University of California at Los Angeles, Los Angeles, California, \\ USA
}

\begin{abstract}
Psychotropic substance abuse and addiction are very prevalent among individuals with major psychiatric disorders world wide. However, this significant association is poorly explained. The dopaminergic circuits have been implemented in addiction as well as in schizophrenia. Recently the important role of glutamatergic neurotransmission has gained attention and current theoretical models of psychosis and substance abuse support the role of interactions between glutamate and other neurotransmitters in the patho-physiology of both disorders. However, the identification of the underlying genetic risk factors remains challenging and not a single genomic variant has been identified with certainty, possibly due to important limitations of the methods used. Clinical trials with glutamatergic neurotransmission modulators, even though still controversial, support the role of glutamate in psychosis and justify further research.
\end{abstract}

\section{INTRODUCTION}

Psychotropic substance abuse is prevalent among individuals with severe psychiatric disorders, but this comorbidity is poorly explained. Genetic risk factors such as genomic variants, which carry specific vulnerabilities, and environmental risk factors, such as stress or exposure to substances of abuse at certain times during the life span have been proposed in both conditions. The fact that substance abuse is found more frequently among people with severe mental illness than in the general population has even led to the hypothesis that both conditions might be causally related [1]. Substances of abuse, such as phencyclidine (PCP), a non-competitive glutamate receptor antagonist, cocaine, a dopamine-transporter antagonist, or amphetamine, which reverses the transport of dopamine and blocks the dopamine transporter, produce psychotic symptoms often indistinguishable from symptoms seen in bipolar disorder (BPD) or schizophrenia (SZ) [2]. The overlapping and strikingly similar symptoms of these conditions suggest that substance induced psychosis and endogenous delusion in mental disorders may use the same neuro-physiological pathways and may share a common psychopathology. However, only a few studies have actually compared the pathological changes in specific brain regions across disorders [3].

\section{THE DOPAMINE SYSTEM}

Evidence for the involvement of the dopamine system in psychosis first came from the observation that dopamine production and release in the nucleus accumbens (NAc) were increased in some unmedicated patients with SZ during the acute stage of the disease [4]. However, variability of this finding suggested that the pathophysiology of SZ might be

*Address correspondence to this author at the Department of Psychiatry and Biobehavioral Sciences, University of California at Los Angeles, 695 Charles E. Young Drive South, Room 3554A, Box 951761, Los Angeles, CA 90095, USA; Tel: (310) 794-9598; Fax: (310) 794-9613;

E-mail: bkerner@mednet.ucla.edu heterogeneous. First-generation antipsychotic medications, such as chlorpromazine or haloperidol were found to bind to dopamine receptors, predominantly the dopamine receptor subtype 2 (D2), which is highly expressed in the NAc [5, 6].

For several decades, the dopamine theory has been the dominant theory in the attempt to explain psychosis. It proclaims that psychotic symptoms arise from imbalances in dopaminergic neuronal pathways, also known as the mesolimbic pathways, which connect the ventral tegmental area (VTA) with the NAc and the prefrontal cortex (PFC) (Fig. 1). The majority of cells in the NAc are gammaaminobutyric acid (GABA) producing inhibitory neurons that connect the NAc with the thalamus. The VTA is a brain structure involved in reward mechanisms and motivation, whereas the thalamus represents a filter for sensory input to the PFC. Inhibitory pathways from the NAc act on thalamocortical connections and protect the cortex from sensory overload and hyper-arousal. Therefore, increased dopamine release in the NAc secondary to imbalances in the mesolimbic pathways could affect GABAergic inhibition. A decrease in GABAergic neurotransmission could then lead to a breakdown of this gating system and subsequent manifestation of psychotic symptoms [7]. The important role of imbalances in the excitatory and inhibitory connections among those central brain regions has been the focus of excellent recent reviews [8] and should therefore not be the topic of this article.

The dopamine system has been extensively studied in addiction as well. Most psychotropic drugs increase dopamine release in the NAc and especially in the initial stages of drug abuse, activation of dopamine cells in the VTA seems to transmit the rewarding effects of drug use. Consequently this effect motivates the repeated use. Recent reviews have focused on dopamine in addiction and the interested reader is referred to these publications $[9,10]$.

\section{THE GLUTAMATE SYSTEM}

Glutamate is the major excitatory neurotransmitter in the brain. It is involved in synaptic plasticity during develop- 


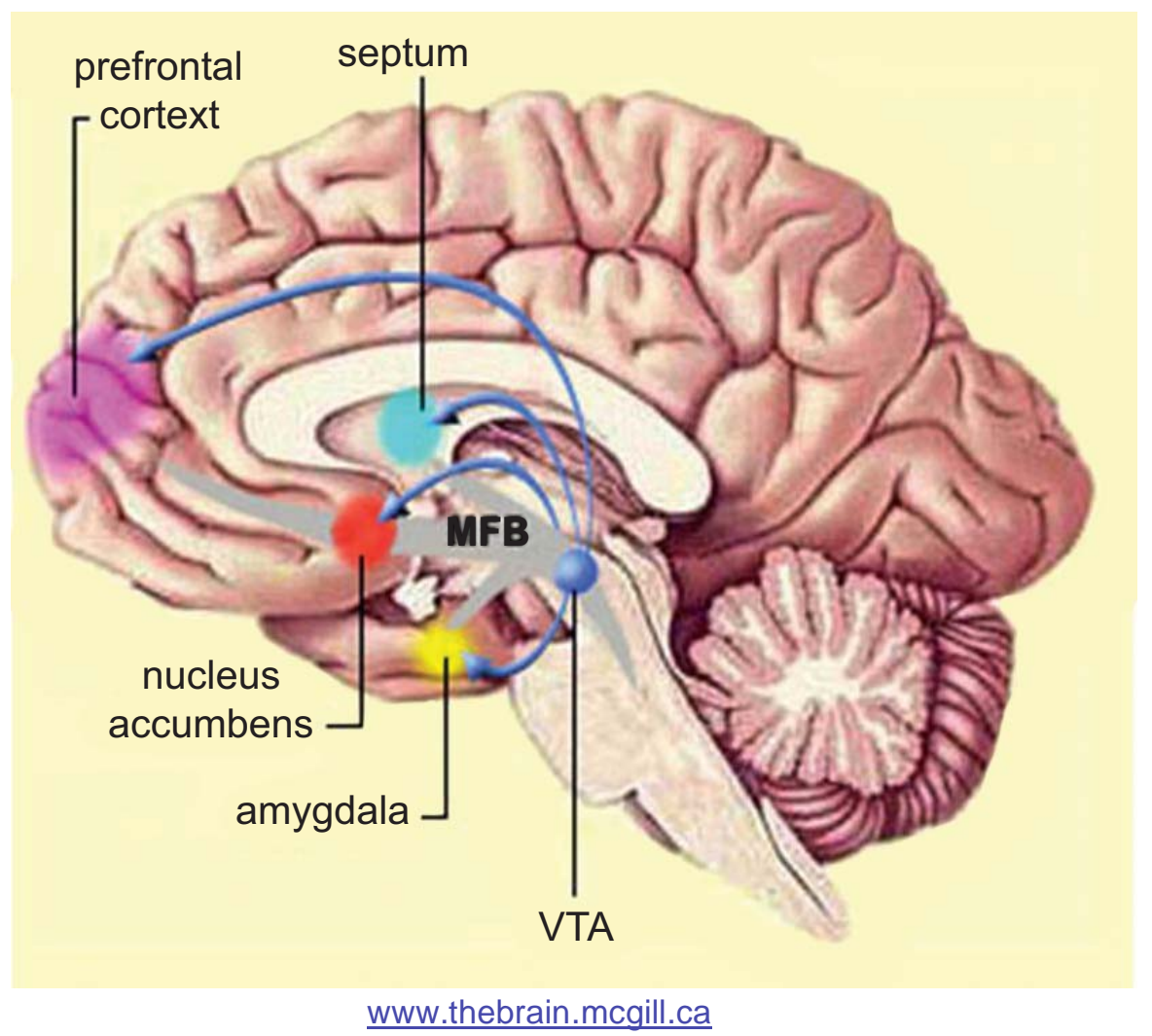

Fig. (1). This graph of the human brain demonstrates the dopaminergic connections from the ventral tegmental area (VTA) to the amygdala and the nucleus accumbens, as well as to areas located in the septum and the prefrontal cortex. The medial forebrain bundle (MFB) contains the dopaminergic mesocorticolimbic pathway, as well as other ascending and descending neuronal tracts.

ment, memory, learning, and motor activity. The substrate of learning and memory is believed to be encoded in long term potentiations (LTP), which are excitatory currents that lead to changes in synaptic plasticity [10]. Major glutamatergic circuits connect the prefrontal cortex with the NAc and the VTA. The NAc receives also glutamatergic stimulation from the hippocampus and the amygdala, two limbic brain structures that are involved in long-term memory, especially spatial memory and memories of emotional reactions.

Attention to the glutamatergic neurotransmitter system in psychosis came from the observation that PCP, which is a glutamatergic N-methyl-D-aspartate (NMDA) receptor antagonist, could induce psychotic symptoms in humans and addiction-like behavior in animals [11, 12]. Functional magnetic resonance imaging (fMRI) studies in healthy human volunteers revealed that the systemic injection of the NMDA receptor antagonist ketamine led to rapid decrease in the regional blood oxygenation-level dependent (BOLD) signal in the ventromedial frontal cortex. Increased signals were detected in temporal cortical regions and in the thalamus. The glutamate-release inhibitor lamotrigine attenuated the signal [13].

The psychogenic effects of glutamate antagonists are not limited to the NMDA receptor alone. Non-competitive antagonists to the ionotropic (ion channel) NMDA glutamate receptor (such as PCP, MK-801 and ketamine), as well as the alpha-amino-3-hydroxy-5-methyl-4-isoxazole propionic acid (AMPA) receptor (such as GYKI52466), can induce psy- chotic symptoms [14, 15]. In addition, kainate, an agonist to a third glutamate receptor subtype can induce imbalances in the dopamine system and psychotic symptoms in humans. The AMPA receptor is a fast, excitatory glutamate receptor and its activation results in depolarization of the synaptic terminal. The tetrameric ion channel consists of a pair of two homo/heteromer dimers, which are composed of GRIA1-4 subunits. The ratio of GRIA1 and GRIA2 receptor subunits determines the $\mathrm{Ca}^{2+}$ permeability of the channel. The AMPA receptor insertion into the postsynaptic membrane of excitatory synapses mediates both synaptic strength, as well as structural changes, such as increase in spine size [16]. The receptor is also involved in the homeostatic adaptation of glutamatergic synapses after stimulation for an extended period of time. This process is often referred to as homeostatic synaptic scaling. It involves an increase in the strength of synapses that have had experienced a decrease in activation. On the other hand, a decrease in the synaptic strength occurs after prolonged activation. Therefore, this mechanism ensures that the strength of the individual synapse is kept within a certain optimal range [17].

AMPA receptor trafficking and phosphorylation in the hippocampus have been linked to mania and depression in BPD. Pharmacological studies in mice have found strong effects of anti-manic and anti-depressive drugs on glutamate receptor expression [18, 19]. Chronic treatment of rats with lithium or valproate significantly reduced the GluR1 expression in rat hippocampus. In addition, the GluR1-specific in- 
hibitor GYKI52466 reduced amphetamine-induced hyperactivity in these animals [20-22]. This model is often compared to manic symptoms in humans. In contrast, conventional anti-depressants or electroconvulsive therapy (ECT) upregulate AMPA receptor expression [23, 24]. Psychostimulants, dopamine agonists, and sleep deprivation also increased phosphorylation and/or synaptic levels of GluR1 receptors in rat hippocampus [22]. It could be demonstrated that repeated administration of haloperidol, a first generation anti-psychotic drug, reduced the expression of NMDA receptor subunits, as well as the AMPA receptor subunit GRIA1. This effect was not observed with olanzapine, a second generation anti-psychotic, which might explain the cognitive side effects of first generation anti-psychotics. These experiments support the hypothesis that imbalances, particularly in the AMPA receptor expression might be involved in psychosis and mood disorders.

The NMDA and AMPA glutamate receptors have not only been linked to mania and psychosis, but also to cocaine seeking behavior and addiction in rats [25]. A single dose of cocaine could increase the AMPA receptor expression and change the receptor subunit composition in dopaminergic cells of the VTA [26]. AMPA receptor up-regulation was also observed after repeated administration of other addictive drugs, such as morphine, ethanol, nicotine, and even after stress [27]. On the other hand, the elevated expression of a particular AMPA receptor subunit gene GRIA1 in the NAc shell significantly increased the intracranial self-stimulation threshold in rats [14]. Based on these findings it was hypothesized that substances of abuse could act on the endogenous systems of synaptic plasticity, reward and learning and through re-setting and modification of these systems could increase the vulnerability to relapse [28].

Ionotrophic glutamate receptors are not the only receptors that transmit glutamatergic signals in the brain. Metabotropic glutamate receptors (mGluR) that are coupled to G-proteins are located on the postsynaptic site as well as on the presynaptic site of glutamatergic synapses. The mGluRs are involved in the modulation of the glutamatergic signal through coupling with the NMDA receptor or through regulation of glutamate release in a negative feedback loop. The potential role of these receptors in mental disorders has been reviewed recently [29-31]. Even though evidence for the involvement of synaptic plasticity in psychosis and addiction is increasing [32], this view is not without challenges. Antagonists to the glutamate receptors also increase dopamine release in the striatum. Certain antagonists change the expression of D2 receptors in the VTA and even bind to these receptors [33]. Interactions between the glutamate and the dopamine system are prevalent and the specific effects of these neurotransmitter systems are difficult to deduct. The psychogenic actions of NMDA antagonists involve not only the dopamine system. Especially serotonin (5-hydroxytryptamine (5-HT)) turnover and release have been detected more consistently than dopamine release after injection of NMDA receptor antagonists. On the other hand, glutamate release in the prefrontal cortex has been induced through the activation of $5-\mathrm{HT}_{2 \mathrm{~A}}$ receptors and antagonists to the metabotropic glutamate 2/3 (mGluR2/3) receptor could block this release [34]. Selective 5- $\mathrm{HT}_{2 \mathrm{~A}}$ receptor agonists, such as mescaline, psilocybin and lysergic acid diethylamide (LSD) can induce psychotic symptoms in humans [35]. The 5- $\mathrm{HT}_{2 \mathrm{~A}}$ receptor can bind hallucinogenic and non-hallucinogenic substances. Until recently, it has been unclear, how the specific response induced by these two different ligands could be mediated by the same receptor. However, recent findings have demonstrated that hallucinogenic drugs can induce a unique cellular response mediated through the co-activation of the $5-\mathrm{HT}_{2 \mathrm{~A}}$ receptor and mGluR2/3. The binding of hallucinogenic drugs to the 5- $\mathrm{HT}_{2 \mathrm{~A}}$ receptor led to the simultaneous activation of both receptors. This resulted in a particular pattern of G-protein activation and specific changes in gene expression. These changes were distinct from cellular responses after non-hallucinogenic drug binding, which did not involve mGluR2/3 activation [35, 36]. This study demonstrated that $5-\mathrm{HT}_{2 \mathrm{~A}}$ receptors and the mGluR2/3 receptor could form functional complexes in the membranes of cortical neurons. This interaction could then lead to specific changes in ligand affinity and second messenger activation. This finding was the first demonstration of a direct interaction between glutamatergic and serotonergic neurotransmitter systems. It illustrated how crosstalk between receptor subtypes could modify the response to particular ligands.

\section{ANIMAL MODELS}

Animal models have traditionally been used to study the biological effect of psychogenic substances and they have consistently provided evidence for the involvement of the glutamate neurotransmitter system in drug abuse and psychosis. A classic example is the injection of PCP, which causes hyperactivity and decreased social interaction in rats. Depression-like behavior, as indicated by immobility in the forced-swim test and impairment in certain cognitive tasks, especially learning and memory have been observed as well. After implantation of electrodes in the prefrontal cortex, ketamine diminished the transmission of the glutamate signal at synapses in the NAc, but it also decreased the neuronal activity of GABA interrneurons in the prefrontal cortex. The overall neuronal activity of prefrontal pyramidal neurons increased, possibly because of desinhibition of these neurons [37]. A recent review summarized these results [38].

In addition, sophisticated genetic manipulation in animals has demonstrated the behavioral effect of mutations in some of the target molecules of psychotropic drugs. Knock-out (KO) mice for the AMPA receptor subunit GRIA1 showed normal neuro-anatomy, but abnormal receptor subunit composition in the hippocampus [39, 40]. KO mice for the entire AMPA receptor demonstrated disruption of stimulus-reward learning and deficits in neurocognitive tests, such as spatial working memory, an abnormality frequently found in psychotic patients. Knock-in mice for a phosphorylation site in the GRIA1 receptor subunit demonstrated deficits in synaptic currents, as well as memory deficits in spatial learning tasks [41].

\section{POST MORTEM STUDIES}

Region and disease specific alterations in glutamate receptor expression have been repeatedly observed in postmor- 
tem brain studies in patients with SZ and to a lesser extend in BPD (Table 1) [42-44]. A recent study found abnormal NMDA receptor subunit composition and alterations in intracellular signaling proteins in the dorsolateral prefrontal cortex of individuals with SZ, BPD and major depressive disorder (MDD) [45]. These results have been replicated in a study, in which laser capture micro-dissection was used to explore gene expression of NMDA and AMPA receptor subunits in Layer II/III and Layer V pyramidal cells in this brain region [46]. In addition, region and disease specific alterations in subunit gene expression of the AMPA receptor subunit GRIA1 was found in medial temporal lobe, and especially in the hippocampus of SZ brains [44, 47]. Immunostaining confirmed reduced protein expression and binding of the AMPA receptor subunit GRIA1. However, studies on glutamate receptor expression and composition in other brain regions have not always been consistent [47-49]. Increased binding has been detected for the kainate receptor in multiple cortical areas and decreased expression was found in the hippocampus. In addition, receptor modifications have been observed affecting calcium influx in the PFC and the striatum. An increase in activity-dependent gene expression has been observed in glutamatergic neurons of the cerebellar cortex in patients with SZ [50,51]. These studies have supported the role of glutamate neurotransmission in psychotic disorders.

\section{GENETIC FACTORS}

Psychosis has been found to aggregate in families [52]. Genetic contributions to the disease are supported by twin studies that found a higher concordance rate for psychotic symptoms in monozygotic twins compared to dizygotic twins [53]. These facts suggest that genetic factors may play a significant role in the psychopathology of psychotic disorders. However, the identification of genomic variants associated with these disorders has been challenging.

Genome-wide linkage studies in large extended families, nuclear families and sib pairs have attempted to identify chromosomal regions that might harbor genomic risk variants for mental disorders [54]. The failure to replicate most of the findings made the interpretation of these signals diffi- cult. The identified regions might harbor rare genomic abnormalities that segregate in subsets of families and in these particular families, these variants might have a moderate to large effect. Nonetheless, the contributions to the overall phenotype and the frequency in patient populations remain unclear. Interestingly, fine mapping of some of the identified chromosomal regions discovered genomic variants that accumulate in certain pathways, such as the glutamatergic and dopaminergic pathways. They also affected genes involved in neuronal cell migration. The cumulative effect of rare mutations in individual families in certain pathways might explain the high and consistent prevalence of psychiatric disorders.

An alternative approach to the identification of genetic risk factors is the genome-wide case-control association study design with single nucleotide polymorphisms (SNPs) in large population samples. These studies aim to identify genomic regions that may contain common risk variants with small to moderate effects. Even though no single genomic variant has been identified and replicated with genome-wide significance in these studies, some interesting signals occurred in genomic regions harboring genes involved in glutamate neurotransmission [55]. The overall risk of developing a mental disorder associated with individual genomic variances was generally small.

Most recent trends in the hunt for genetic risk factors focus on the identification of small structural genomic variants, such as deletions, inversion, and duplications of genomic regions, as well as copy number variations (CNVs). Several CNVs have been identified in patients with SZ and BPD. Three out of four genes that contained these genomic variations were involved in glutamate signaling [56]. A recent study in a small sample of SZ patients found that the overall frequency of these structural variations was significantly higher in the patient group compared to the control group. The abnormalities affected several genes in neurotransmitter pathways involved in psychosis or drug abuse [57].

Studies on the genetics of substance abuse and addiction have had very similar results. Family, twin and adoption

Table 1. Neurotransmitter Receptor Distribution and Alterations in Postmortem Studies of SZ [44, 48]

\begin{tabular}{|c|c|c|c|}
\hline Neurotransmitter Receptor & Location & Ligand & Changes in Postmortem Brains (SZ) \\
\hline NMDA & $\begin{array}{c}\text { cortex } \\
\text { ventral striatum } \\
\text { hippocampus } \\
\text { amygdale }\end{array}$ & $\begin{array}{c}\text { PCP } \\
\text { ketamine } \\
\left({ }^{3} \mathrm{H}\right) \mathrm{MK}-801 \\
\left({ }^{3} \mathrm{H}\right) \text { glycine }\end{array}$ & $\begin{array}{c}(\uparrow) \text { increased binding and expression in multiple cortical areas and possibly } \\
\text { putamen }\end{array}$ \\
\hline AMPA & $\begin{array}{c}\text { cortex } \\
\text { ventral striatum } \\
\text { hippocampus } \\
\text { amygdala }\end{array}$ & $\begin{array}{c}\text { AMPA } \\
\text { GYKI52466 }\end{array}$ & $\begin{array}{c}\uparrow \text { cortex } \\
\downarrow \text { hippocampus }\end{array}$ \\
\hline Kainate & $\begin{array}{l}\text { cortex } \\
\text { hippocampus } \\
\text { cerebellum }\end{array}$ & $\left({ }^{3} \mathrm{H}\right)$ kainate & $\begin{array}{c}\uparrow \text { cortex } \\
\downarrow \text { hippocampus }\end{array}$ \\
\hline mGluR2 & $\begin{array}{c}\text { Cortex } \\
\text { Dentate gyrus }\end{array}$ & LY379268 & \\
\hline
\end{tabular}


studies have provided strong evidence for heritability of addiction for all subclasses of abused substances, however, no genetic variant associated with substance abuse has been identified with certainty [58]. Well powered genome-wide case-control studies on SNPs and CNVs in addiction will reveal better insight into the patho-mechanisms of these disorders.

\section{LIMITATIONS}

The race for a biological explanation of the abnormalities seen in psychiatric disorders has many hurdles. Some technical limitations may explain part of the problem. The currently available genome-wide SNP arrays are designed to detect common genomic variants in high linkage disequilibrium with selected tagging SNPs relatively evenly distributed throughout the genome [59]. This approach can only point to genomic regions that might be associated with a disease, but often fails to identify functional variants. Genomic variants in highly polymorphic regions and in regions with low linkage disequilibrium are often missed. However, it appears to be likely that subtle differences in gene expression levels regulated by genomic variants in highly variable regulatory regions are the root cause of neurophysiologic abnormalities. These regulatory elements can be close to the genes (cisregulatory elements) or even act over greater distances away from coding regions (trans-regulatory elements). Our knowledge about gene expression regulation is still incomplete. Regulation of gene expression might involve intronic sequences, micro-ribonucleic acids (microRNAs), and intergenic non-coding regions of the genome. The current technologies do not allow us to explore these issues completely. Direct sequencing of candidate gene regions might be required in order to detect genomic variations that might explain psychiatric symptoms.

Overall, genes involved in glutamatergic neurotransmission are not well explored in current studies due to their complex genomic structure. Especially, intron sequences are poorly covered, because these regions are highly polymorphic and rich in copy number repeats. This fact challenges the analysis with currently available methods, as well as the interpretation of the results $[60,61]$. For example, in GRIA1, 1394 SNPs can be found in the National Center for Biotechnology Information (NCBI) data base (http://www.ncbi.nlm. nih.gov/SNP, November 2008). The majority of these SNPs are located in intron sequences. However, only a very small percentage is represented on the commercially available GeneChip arrays. Those intron sequences may play a major role in gene expression regulation $[62,63]$. In addition, evidence is emerging that a major source of variability between two individual genomes is encoded in structural variations, especially deletions, insertions, inversions and duplications of genetic material. The ability to detect these genomic variants with current SNP microarray technology is limited. The cumulative evidence of the importance of structural variants in psychosis and the information gap in genome-wide association studies justify further studies.

\section{CLINICAL STUDIES}

Considerable effort has been made to develop specific glutamate receptor antagonists and modulators, based on accumulating evidence for the importance of glutamatergic neurotransmission in psychotic disorders. Both glutamate agonists, as well as antagonists have been tried in animal models and in humans; however, the results have been inconsistent.

Due to potential neurotoxicity, direct agonists of the NMDA receptor have not been used in clinical trials. Instead, modulators of the glycine binding site of the receptor, such as glycine, D-cycloserine, and D-alanine, have been more promising, especially in combination with typical and atypical antipsychotics [64]. These results, however, have not always been confirmed, and therefore, the enthusiasm about NMDA receptor modulators has declined [65]. Some evidence exists that modulators of the NMDA receptor are more effective in combination with typical anti-psychotics compared to atypical anti-psychotics.

The modulators of the AMPA receptor, such as ampakines, which selectively enhance glutamatergic neurotransmission, have improved cognitive deficits in SZ patients treated with clozapine in some studies [11].

The newest targets in these approaches are modulators of the metabotropic glutamate receptors. Mono-therapy with a selective agonist for the mGluR2/3 has led to significant improvement in both positive, as well as negative symptoms without the common side effects of atypical anti-psychotics [66].

The importance of glutamate in mood disorders has lately drawn attention [67] The NMDA receptor antagonist ketamine has been reported to have strong and fast acting antidepressant effects [68] and modulators of the AMPA receptor have been shown to be advantageous in the treatment of depression and anxiety [69]. In fact, an extensive review of metabotropic glutamate receptor modulators has indicated their benefit for the treatment of mood and anxiety disorders [70].

New and currently tested anti-psychotic drugs, such as JL 13, might attenuate glutamatergic transmission in the PFC and in the basal ganglia through their effect on the NMDA and AMPA receptors, as well as through interaction with 5$\mathrm{HT}_{2 \mathrm{~A}}$ and $\alpha 1$-adrenoceptors [71-73].

Even though still controversial, these studies support the role of glutamate in psychosis and justify further research in this important area. Based on these recent findings, new drugs for SZ are under development [74]. However, studies in BPD patients have not been conducted to date.

\section{CONCLUSIONS}

Psychiatric disorders are often associated with substance abuse and psychosis. Several theories attempt to explain this correlation. The experience of hallucinations and delusions is, most likely, a common endpoint to a number of neurophysiologic abnormalities. The striking inability of patients with BPD and SZ, however, to maintain balance and the increased vulnerability to addiction may indicate that certain abnormalities in homeostatic mechanisms are at the core of these phenotypes. The fact that substance abuse and dependence are so prevalent in this patient population may not only 
be an unfortunate coincidence, but it may point to core pathophysiologic abnormalities in a subgroup of patients. Exploration of these correlations could help to improve our understanding of these psychotic disorders, their genetic risk factors and gene/environment interactions. Most of all, it could open up opportunities for the development of new and improved treatment options, as well as early diagnosis and intervention.

\section{ABBREVIATIONS}

\begin{tabular}{|c|c|c|}
\hline PCP & $=$ & Phencyclidine \\
\hline BPD & $=$ & Bipolar disorder \\
\hline $\mathrm{SZ}$ & $=$ & Schizophrenia \\
\hline MFB & $=$ & Medial forebrain bundle \\
\hline NAc & $=$ & Nucleus accumbens \\
\hline D2 & $=$ & Dopamine receptor subtype 2 \\
\hline VTA & $=$ & Ventral tegmental area \\
\hline PFC & $=$ & Prefrontal cortex \\
\hline GABA & $=$ & Gamma-aminobutyric acid \\
\hline LTP & $=$ & Long term potentiations \\
\hline NMDA & $=$ & N-methyl-D-aspartate \\
\hline fMRI & $=$ & Functional magnetic resonance imaging \\
\hline BOLD & $=$ & $\begin{array}{l}\text { Regional blood oxygenation level- } \\
\text { dependent }\end{array}$ \\
\hline AMPA & $=$ & $\begin{array}{l}\text { Alpha-amino-3-hydroxy-5-methyl-4- } \\
\text { isoxazole propionic acid }\end{array}$ \\
\hline GRIA & $=$ & AMPA receptor gene \\
\hline GRIA1-4 & $=$ & AMPA receptor subunit genes 1-4 \\
\hline GluR1 & $=$ & Murine glutamate receptor subunit 1 \\
\hline ECT & $=$ & Electroconvulsive therapy \\
\hline mGluR & $=$ & Metabotropic glutamate receptor \\
\hline $5-\mathrm{HT}$ & $=$ & 5-Hydroxy-tryptamine \\
\hline $5-\mathrm{HT}_{2 \mathrm{~A}}$ & $=$ & 5-Hydroxy-tryptamine $2 \mathrm{~A}$ receptor \\
\hline mGluR2/3 & $=$ & Metabotropic glutamate $2 / 3$ receptor \\
\hline LSD & $=$ & Lysergic acid diethylamide \\
\hline $\mathrm{KO}$ & $=$ & Knock-out \\
\hline $\mathrm{KI}$ & $=$ & Knock-in \\
\hline MDD & $=$ & Major depressive disorder \\
\hline SNP & $=$ & Single nucleotide polymorphism \\
\hline $\mathrm{CNV}$ & $=$ & Copy number variation \\
\hline RNA & $=$ & Ribonucleic acid \\
\hline
\end{tabular}

\section{ACKNOWLEDGEMENT}

This work was supported in part by the NIMH grant K08 MH074057-01 and a NARSAD Young Investigator Award to Berit Kerner.

\section{CONFLICT OF INTEREST}

The author declares to have no conflict of interest.

\section{REFERENCES}

[1] Ringen PA, Melle I, Birkenaes AB, et al. Illicit drug use in patients with psychotic disorders compared with that in the general population: a cross-sectional study. Acta Psychiatr Scand 2008; 117: 1338.

[2] Krystal JH, Perry EB Jr, Gueorguieva R, et al. Comparative and interactive human psychopharmacologic effects of ketamine and amphetamine: implications for glutamatergic and dopaminergic model psychoses and cognitive function. Arch Gen Psychiatry 2005; 62: 985-94.

[3] Moghaddam B, Homayoun H. Divergent plasticity of prefrontal cortex networks. Neuropsychopharmacology 2008; 33: 42-55.

[4] Laruelle M, Abi-Dargham A, van Dyck CH, et al. Single photon emission computerized tomography imaging of amphetamineinduced dopamine release in drug-free schizophrenic subjects. Proc Natl Acad Sci USA 1996; 93: 9235-40.

[5] Seeman P, Weinshenker D, Quirion R, et al. Dopamine supersensitivity correlates with D2 High states, implying many paths to psychosis. Proc Natl Acad Sci USA 2005; 102: 3513-8

[6] Carlsson A. The neurochemical circuitry of schizophrenia. Pharmacopsychiatry 2006; 39: S10-S14.

[7] Carlsson A, Waters N, Holm-Waters S, Tedroff J, Nilsson M, Carlsson ML. Interactions between monoamines, glutamate, and GABA in schizophrenia: new evidence. Annu Rev Pharmacol Toxicol 2001; 41: 237-60.

[8] Lewis DA, González-Burgos G. Neuroplasticity of neocortical circuits in schizophrenia. Neuropsychopharmacology 2008; 33: 141-65.

[9] El-Ghundi M, O'Dowd BF, George SR. Insights into the role of dopamine receptor systems in learning and memory. Rev Neurosci 2007; 18: 37-66.

[10] Citri A, Malenka RC. Synaptic plasticity: multiple forms, functions, and mechanisms. Neuropsychopharmacology 2008; 33: 1841.

[11] Goff DC, Coyle JT. The emerging role of glutamate in the pathophysiology and treatment of schizophrenia. Am J Psychiatry 2001; 158: 1367-77.

[12] Tsai G, Coyle JT. Glutamatergic mechanisms in schizophrenia. Annu Rev Pharmacol Toxicol 2002; 42: 165-79.

[13] Deakin JF, Lees J, McKie S, Hallak JE, Williams SR, Dursun SM. Glutamate and the neural basis of the subjective effects of ketamine: a pharmaco-magnetic resonance imaging study. Arch Gen Psychiatry 2008; 65: 154-64.

[14] Todtenkopf MS, Parsegian A, Naydenov A, Neve RL, Konradi C, Carlezon WA Jr. Brain reward regulated by AMPA receptor subunits in nucleus accumbens shell. J Neurosci 2006; 26: 11665-9.

[15] Svensson TH, Mathé JM. Atypical antipsychotic-like effect of AMPA receptor antagonists in the rat. Amino Acids 2000; 19: 2216.

[16] Kopec CD, Real E, Kessels HW, Malinow R. GluR1 links structural and functional plasticity at excitatory synapses. J Neurosci 2007; 27: 13706-18.

[17] Turrigiano GG, Nelson SB. Homeostatic plasticity in the developing nervous system. Nat Rev Neurosci 2004; 5: 97-107.

[18] Del'guidice T, Beaulieu JM. Messing up with traffic: different effects of antipsychotic agents on glutamate receptor complexes in vivo. Mol Pharmacol 2008; 73: 1339-42.

[19] Fumagalli F, Frasca A, Racagni G, Riva MA. Dynamic regulation of glutamatergic postsynaptic activity in rat prefrontal cortex by repeated administration of antipsychotic drugs. Mol Pharmacol 2008; 73: 1484-90.

[20] Gould TD, O'Donnell KC, Dow ER, Du J, Chen G, Manji HK. Involvement of AMPA receptors in the antidepressant-like effects of lithium in the mouse tail suspension test and forced swim test. Neuropharmacology 2008; 54: 577-87.

[21] Du J, Suzuki K, Wei Y, et al. The anticonvulsants lamotrigine, riluzole, and valproate differentially regulate AMPA receptor membrane localization: relationship to clinical effects in mood disorders. Neuropsychopharmacology 2007; 32: 793-802.

[22] Du J, Creson TK, Wu LJ, et al. The role of hippocampal GluR1 and GluR2 receptors in manic-like behavior. J Neurosci 2008; 28 68-79. 
[23] Martinez-Turrillas R, Frechilla D, Del Río J. Chronic antidepressant treatment increases the membrane expression of AMPA receptors in rat hippocampus. Neuropharmacology 2002; 43: 1230-7.

[24] Du J, Gray NA, Falke C, Yuan P, Szabo S, Manji HK. Structurally dissimilar antimanic agents modulate synaptic plasticity by regulating AMPA glutamate receptor subunit GluR1 synaptic expression. Ann N Y Acad Sci 2003; 1003: 378-80.

[25] Kauer JA, Malenka RC. Synaptic plasticity and addiction. Nat Rev Neurosci 2007; 8: 844-58.

[26] Argilli E, Sibley DR, Malenka RC, England PM, Bonci A. Mechanism and time course of cocaine-induced long-term potentiation in the ventral tegmental area. J Neurosci 2008; 28: 9092-1000.

[27] Saal D, Dong Y, Bonci A, Malenka RC. Drugs of abuse and stress trigger a common synaptic adaptation in dopamine neurons. Neuron 2003; 37: 577-82. Erratum in: Neuron 2003; 38: 359.

[28] Kalivas PW, Lalumiere RT, Knackstedt L, Shen H. Glutamate transmission in addiction. Neuropharmacology 2008; [Epub ahead of print, November 2008].

[29] Darrah JM, Stefani MR, Moghaddam B. Interaction of N-methylD-aspartate and group 5 metabotropic glutamate receptors on behavioral flexibility using a novel operant set-shift paradigm. Behav Pharmacol 2008; 19: 225-34.

[30] Pilc A, Chaki S, Nowak G, Witkin JM. Mood disorders: regulation by metabotropic glutamate receptors. Biochem Pharmacol 2008; 75: 997-1006.

[31] Witkin JM, Marek GJ, Johnson BG, Schoepp DD. Metabotropic glutamate receptors in the control of mood disorders. CNS Neurol Disord Drug Targets 2007; 6: 87-100.

[32] Gass JT, Olive MF. Glutamatergic substrates of drug addiction and alcoholism. Biochem Pharmacol 2008; 75: 218-65.

[33] Healy DJ, Meador-Woodruff JH. Differential regulation, by MK801, of dopamine receptor gene expression in rat nigrostriatal and mesocorticolimbic systems. Brain Res 1996; 708: 38-44.

[34] Marek GJ, Wright RA, Schoepp DD, Monn JA, Aghajanian GK. Physiological antagonism between 5-hydroxytryptamine (2A) and group II metabotropic glutamate receptors in prefrontal cortex. J Pharmacol Exp Ther 2000; 292: 76-87.

[35] González-Maeso J, Weisstaub NV, Zhou M, et al. Hallucinogens recruit specific cortical 5-HT(2A) receptor-mediated signaling pathways to affect behavior. Neuron 2007; 53: 439-52.

[36] González-Maeso J, Ang RL, Yuen T, et al. Identification of a serotonin/glutamate receptor complex implicated in psychosis. Nature 2008; 452: 93-7.

[37] Homayoun H, Moghaddam B. NMDA receptor hypofunction produces opposite effects on prefrontal cortex interneurons and pyramidal neurons. J Neurosci 2007; 27: 11496-500.

[38] Mouri A, Noda Y, Enomoto T, Nabeshima T. Phencyclidine animal models of schizophrenia: approaches from abnormality of glutamatergic neurotransmission and neurodevelopment. Neurochem Int 2007; 51: 173-84.

[39] Reisel D, Bannerman DM, Schmitt WB, et al. Spatial memory dissociations in mice lacking GluR1. Nat Neurosci 2002; 5: 86873.

[40] Mead AN, Stephens DN. Selective disruption of stimulus-reward learning in glutamate receptor gria1 knock-out mice. J Neurosci 2003; 23: 1041-8.

[41] Lee HK, Takamiya K, Han JS, et al. Phosphorylation of the AMPA receptor GluR1 subunit is required for synaptic plasticity and retention of spatial memory. Cell 2003; 112: 631-43.

[42] Eastwood SL, McDonald B, Burnet PW, Beckwith JP, Kerwin RW, Harrison PJ. Decreased expression of mRNAs encoding nonNMDA glutamate receptors GluR1 and GluR2 in medial temporal lobe neurons in schizophrenia. Brain Res Mol Brain Res 1995; 29: 211-23.

[43] Kristiansen LV, Huerta I, Beneyto M, Meador-Woodruff JH. NMDA receptors and schizophrenia. Curr Opin Pharmacol 2007; 7: 48-55.

[44] Meador-Woodruff JH, Healy DJ. Glutamate receptor expression in schizophrenic brain. Brain Res Brain Res Rev 2000; 31: 288-94.

[45] Beneyto M, Kristiansen LV, Oni-Orisan A, McCullumsmith RE, Meador-Woodruff JH. Abnormal glutamate receptor expression in the medial temporal lobe in schizophrenia and mood disorders. Neuropsychopharmacology 2007; 32: 1888-902.

[46] O'Connor JA, Muly EC, Arnold SE, Hemby SE. AMPA receptor subunit and splice variant expression in the DLPFC of schizo- phrenic subjects and rhesus monkeys chronically administered antipsychotic drugs. Schizophr Res 2007; 90: 28-40.

[47] Beneyto M, Meador-Woodruff JH. Lamina-specific abnormalities of NMDA receptor-associated postsynaptic protein transcripts in the prefrontal cortex in schizophrenia and bipolar disorder. Neuropsychopharmacology 2008; 33: 2175-86.

[48] Kristiansen LV, Beneyto M, Haroutunian V, Meador-Woodruff JH. Changes in NMDA receptor subunits and interacting PSD proteins in dorsolateral prefrontal and anterior cingulate cortex indicate abnormal regional expression in schizophrenia. Mol Psychiatry 2006; 11: 737-47.

[49] O'Connor JA, Hemby SE. Elevated GRIA1 mRNA expression in Layer II/III and V pyramidal cells of the DLPFC in schizophrenia. Schizophr Res 2007; 97: 277-88.

[50] Akbarian S, Smith MA, Jones EG. Editing for an AMPA receptor subunit RNA in prefrontal cortex and striatum in Alzheimer's disease, Huntington's disease and schizophrenia. Brain Res 1995; 699: 297-304.

[51] Paz RD, Andreasen NC, Daoud SZ, et al. Increased expression of activity-dependent genes in cerebellar glutamatergic neurons of patients with schizophrenia. Am J Psychiatry 2006; 163: 1829-31.

[52] Kendler KS, Davis CG, Kessler RC. The familial aggregation of common psychiatric and substance use disorders in the National Comorbidity Survey: a family history study. Br J Psychiatry 1997; 170: 541-8.

[53] Cardno AG, Rijsdijk FV, Sham PC, Murray RM, McGuffin P. A twin study of genetic relationships between psychotic symptoms. Am J Psychiatry 2002; 159: 539-45.

[54] Potash JB. Carving chaos: genetics and the classification of mood and psychotic syndromes. Harv Rev Psychiatry 2006; 14: 47-63.

[55] Wellcome Trust Case Control Consortium. Genome-wide association study of 14,000 cases of seven common diseases and 3,000 shared controls. Nature 2007; 447: 661-78.

[56] Wilson GM, Flibotte S, Chopra V, Melnyk BL, Honer WG, Holt RA. DNA copy-number analysis in bipolar disorder and schizophrenia reveals aberrations in genes involved in glutamate signaling. Hum Mol Genet 2006; 15: 743-9.

[57] Walsh T, McClellan JM, McCarthy SE, et al. Rare structural variants disrupt multiple genes in neurodevelopmental pathways in schizophrenia. Science 2008; 320: 539-43.

[58] Ball D. Addiction science and its genetics. Addiction 2008; 103 : 360-7.

[59] Hao K, Schadt EE, Storey JD. Calibrating the performance of SNP arrays for whole-genome association studies. PLoS Genet 2008; 4: e1000109 (November 2008).

[60] Estivill X, Armengol L. Copy number variants and common disorders: filling the gaps and exploring complexity in genome-wide association studies. PLoS Genet 2007; 3: 1787-99.

[61] Topol EJ, Frazer KA. The resequencing imperative. Nat Genet 2007; 4: 439-40.

[62] Nackley AG, Shabalina SA, Tchivileva IE, et al. Human catecholO-methyltransferase haplotypes modulate protein expression by altering mRNA secondary structure. Science 2006; 314: 1930-3.

[63] Kimchi-Sarfaty C, Oh JM, Kim IW, et al. A "silent" polymorphism in the MDR1 gene changes substrate specificity. Science 2007; 315: 525-8.

[64] Javitt DC. Is the glycine site half saturated or half unsaturated? Effects of glutamatergic drugs in schizophrenia patients. Curr Opin Psychiatry 2006; 19: 151-7.

[65] Buchanan RW, Javitt DC, Marder SR, et al. The Cognitive and Negative Symptoms in Schizophrenia Trial (CONSIST): the efficacy of glutamatergic agents for negative symptoms and cognitive impairments. Am J Psychiatry 2007; 164: 1593-602.

[66] Patil ST, Zhang L, Martenyi F, et al. Activation of mGlu2/3 receptors as a new approach to treat schizophrenia: a randomized Phase 2 clinical trial. Nat Med 2007; 13: 1102-7.

[67] Sanacora G, Zarate CA, Krystal JH, Manji HK. Targeting the glutamatergic system to develop novel, improved therapeutics for mood disorders. Nat Rev Drug Discov 2008; 7: 426-37.

[68] Berman RM, Cappiello A, Anand A, et al. Antidepressant effects of ketamine in depressed patients. Biol Psychiatry 2000; 47: 351-4.

[69] Bleakman D, Alt A, Witkin JM. AMPA receptors in the therapeutic management of depression. CNS Neurol Disord Drug Targets 2007; 6: 117-26. 
[70] Lavreysen H, Dautzenberg FM. Therapeutic potential of group III metabotropic glutamate receptors. Curr Med Chem 2008; 15: 67184.

[71] Amargós-Bosch M, Adell A, Artigas F. Antipsychotic drugs reverse the AMPA receptor-stimulated release of 5-HT in the medial prefrontal cortex. J Neurochem 2007; 102: 550-61.

[72] Tarazi FI, Moran-Gates T, Gardner MP, Graulich A, Lamy C, Liégeois JF. Long-term effects of JL 13, a potential atypical antip- sychotic, on ionotropic glutamate receptors. J Mol Neurosci 2007; 32: $192-8$.

[73] Aghajanian GK, Marek GJ. Serotonin model of schizophrenia: emerging role of glutamate mechanisms. Brain Res Brain Res Rev 2000; 31: 302-12.

[74] Gray JA, Roth BL. The pipeline and future of drug development in schizophrenia. Mol Psychiatry 2007; 12: 904-22.

(C) Berit Kerner; Licensee Bentham Open.

This is an open access article licensed under the terms of the Creative Commons Attribution Non-Commercial License (http://creativecommons.org/licenses/by$\mathrm{nc} / 3.0 /$ ) which permits unrestricted, non-commercial use, distribution and reproduction in any medium, provided the work is properly cited. 